\section{Az NPK-trágyázás hatása a kukorica tápelemfelvételének dinamikájára, öntözött és nem öntözött viszonyok között}

\author{
Kincses Sándorné - Filep Tibor - Loch Jakab \\ Debreceni Egyetem Agrártudományi Centrum, \\ Mezögazdaságtudományi Kar, \\ Mezőgazdasági Kémiai Tanszék, Debrecen
}

\section{ÖSSZEFOGLALÁS}

Az NPK-trágyázás hatását vizsgáltuk kukorica (Zea mays L., Clarica) tápelemfelvételének dinamikájára többtényezös szabadföldi kísérletben, egy mészlepedékes csernozjom talajon, öntözött és nem öntözött viszonyok között.

Az NPK kezelések hatása a kukoricánál hasonlóan érvényesült, mint azt a hazai szerzök más növényeknél tapasztalták. Vizsgálataink alapján a következöket állapitottuk meg:

- a növényben mért elemkoncentrációk a tenyészidö elörehaladtával csökkennek,

- az öntözött és nem öntözött kultúrák között nem találtunk különbségeket a tápelemek dinamikájában, mivel a vegetációs idöszak alatt megfelelö mennyiségü csapadék hullott,

- a N-adagok szignifikánsan növelték a növény nitrogéntartalmát, valamint a Ca-és Mg-koncentrációkra is hatással voltak,

- a N-mütrágyák savanyitó hatása következtében a N-adagok emelésekor nött a növény $\mathrm{Mn}$-, Zn- és Cu-tartalma,

- a P-kezelések a mintavételek jelentös részében szignifikánsan befolyásolták a kukorica $P$ - és $N$-tartalmát, valamint a $P-Z n$ antagonizmuson keresztül a Zn-koncentrációkat is,

- a nagy adagú K-kezelések megváltoztatták a talajban az ionarányokat, ennek következtében a növény $\mathrm{Ca}$-, $\mathrm{Mg}$ tartalmának csökkenését okozták.

\section{SUMMARY}

The effect of NPK-fertilization on the dynamics of nutrient uptake of maize (Zea mays L., cv. Clarica) was examined on chernozem soil under irrigated and non-irrigated conditions in a field experiment.

The following results were made:

- the element concentrations in the plant decreased over time,

- there is no difference between the dynamics of nutrients on irrigated and non-irrigated sites because rainfall was satisfactory for plants in vegetation period,

- the $N$ doses not only significantly increase the nitrogen content in maize, but also have a noticable effect on $\mathrm{Ca}$ and Mg concentrations,

- because of the acidifying effect of $N$-fertilizers, increasing the amount of $\mathrm{N}$-fertilizer increased the $\mathrm{Mn}, \mathrm{Zn}, \mathrm{Cu}$ content of the plants,

- the $P$ doses have a significant effect on the maize $P$ and $N$ content and the $Z n$ concentration of the plant via $P-Z n$ antagonism in the soil,

- as the high $K$ doses treatments alter the ion ratios in the soil, the $\mathrm{Ca}, \mathrm{Mg}$ content of the plant decreased.

\section{BEVEZETÉS}

Ismert, hogy a termés mennyiségét alapvetően a kultúrnövények genetikai tulajdonságai, az ökológiai viszonyok és a tápanyagellátás határozzák meg. Különösen fontos a növények tápanyag-ellátottsága a kritikus, intenzív fejlődési szakaszban, amikor nagy mennyiségü tápanyagot vesznek fel naponta. Ezért szükséges a tápelemfelvétel dinamikájának tanulmányozása (Kádár és Lásztity, 1981).

Hazánkban több növényfajjal és talajtípuson végeztek tápelem-dinamikai vizsgálatokat (Kádár és Lásztity, 1997; Lásztity et al., 1981; Lásztity, 1989), mégis a kukorica tápelemfelvételének dinamikájáról különböző talaj és éghajlati viszonyok között, jelentőségéhez képest viszonylag kevés számú publikáció jelent meg. Lásztity és munkatársai (1985a, b) karbonátos homoktalajon tanulmányozták egy kukoricahibrid tápelemfelvételét. $\mathrm{Mi}$ egy mészlepedékes csernozjom talajon beállított szabadföldi kísérlet növényeit vizsgáltuk.

A növény megfelelö fenofázisaiban növénymintákat vettünk, s mértük azok makro- és mikroelem-tartalmát. A tápelemtartalom vizsgálatoknál nemcsak a trágyázással pótolt elemek $(\mathrm{N}, \mathrm{P}, \mathrm{K})$ koncentrációjának mérésére törekedtünk, hanem a kísérő elemekére is, azért, hogy megállapítsuk, miként változik mennyiségük az NPK-trágyázás hatására.

\section{ANYAG ÉS MÓDSZER}

A kukorica (Zea mays L., Clarica) tápelemfelvételének dinamikáját a Debreceni Egyetem Agrártudományi Centrumának látóképi kísérleti telepén, Dr. Ruzsányi László kísérletében vizsgáltuk. A talaj fontosabb fizikai-kémiai jellemzői: $\mathrm{pH}\left(\mathrm{H}_{2} \mathrm{O}\right)$ : 6,7; pH(KCl): 5,9; Humusz (\%): 2,5; Összes-N (\%): 0,$15 ; \quad \mathrm{K}_{\mathrm{A}}: 42 ; \quad \mathrm{AL}-\mathrm{P}_{2} \mathrm{O}_{5} \quad(\mathrm{mg} / \mathrm{kg}): 88 ; \quad \mathrm{AL}-\mathrm{K}_{2} \mathrm{O}$ (mg/kg): 150 .

A többtényezős kísérletet 1988-ban Box és Wilson (1951) kísérlettervezési módszerével, 15 kezeléssel 4 ismétlésben állították be, öntözött és nem öntözött viszonyok között. A kísérlet véletlen blokk elrendezésű, a parcellák mérete: $40 \mathrm{~m}^{2}$. A tervezéshez és értékeléshez Biczók és Tolner számítógépes programját (Loch et al., 1987a, b) használtuk.

Az alkalmazott 15 kezeléskombináció közül hat kezelés adatait dolgoztuk fel. Ezek a következők: $\mathrm{N}_{175}(175 \mathrm{~kg} \mathrm{~N} / \mathrm{ha} / \mathrm{év}) ; \mathrm{N}_{35}$ (35 kg N/ha/év); $\mathrm{P}_{140}(140$ kg $\mathrm{P}_{2} \mathrm{O}_{5} /$ ha/év $) ; \mathrm{P}_{0}\left(0 \mathrm{~kg} \mathrm{P}_{2} \mathrm{O}_{5} / \mathrm{ha} / \mathrm{év}\right) ; \mathrm{K}_{140}(140 \mathrm{~kg}$ $\left.\mathrm{K}_{2} \mathrm{O} / \mathrm{ha} / \mathrm{év}\right) ; \mathrm{K}_{0}(0 \mathrm{~kg} \mathrm{~K} \mathrm{O} / \mathrm{ha} / \mathrm{év})$. A legkisebb és a 
legnagyobb NPK-adagoknál a trágyázással pótolt másik két elem mennyisége középszinten volt (105 $\mathrm{kg} \mathrm{N} / \mathrm{ha} ; 70 \mathrm{~kg} \mathrm{P}_{2} \mathrm{O}_{5} / \mathrm{ha} ; 70 \mathrm{~kg} \mathrm{~K} 2 \mathrm{O} / \mathrm{ha}$ ). Tehát egyegy elem (N, P, K) legkisebb és legnagyobb adagjánál vizsgáltuk a növényben az elemkoncentrációkat, a másik két elem közepes dózisa mellett.

Az öntözött parcellákon a növény vízigényét figyelembe véve, s a talaj víztartalékát is beszámítva, az aktuális csapadékmennyiségtől függően öntöztek. A tenyészidőszak folyamán az $\mathrm{V}$. hónapban: 53,8; VI. hónapban: 117,6; VII. hónapban: 83,5; VIII. hónapban: 24,4 $\mathrm{mm}$ csapadék esett a területen. Dolgozatunkban az 1999. évi kukoricaállomány növénymintáinak vizsgálati eredményeit ismertetjük.

A kukoricát május 2-án vetették el és május 10-én kelt ki. A tenyészidőszakban öt alkalommal vettünk növénymintát, oly módon, hogy parcellánként a növény 4-4 tő földfeletti részét eltávolítottuk. A mintavételek időpontjai és a hozzájuk tartozó fenológiai állapotok a következők:

\section{1. mintavétel: június 2. (a keléstől számított 23. nap)}

$\begin{array}{ll}\text { 2. mintavétel: június 21. (43. nap) } & \text { 3-4 leveles állapot } \\ \text { 3. mintavétel: július 5. (57. nap) } & \text { címerhányás } \\ \text { 4. mintavétel: július 19. (71. nap) } & \text { virágzás } \\ \text { 5. mintavétel: szeptember 7. (121. nap) } & \text { teljes érés. }\end{array}$

$\mathrm{Az}$ 5. mintavétel növénymintáit már szemre, illetve szárra és levélre választottuk szét. A megfelelően előkészített minták elemtartalmát $(\mathrm{K}, \mathrm{P}$, $\mathrm{Ca}, \mathrm{Mg}, \mathrm{Mn}, \mathrm{Zn}, \mathrm{Cu}$ ) ICP-vel, N-tartalmát pedig Kjeldahl módszerrel mértük. A kezeléshatásokat egytényezős varianciaanalízissel értékeltük.

\section{EREDMÉNYEK ÉS ÉRTÉKELÉS}

\section{Nitrogén kezelések hatása a növény elemtartalmára}

Az 1. táblázatban a $\mathrm{N}$-adagok hatását mutatjuk be a kukorica tápelem-koncentrációira. Összességében megállapítható, hogy mind a makro-, mind a mikroelem-koncentrációk a tenyészidő elörehaladtával csökkentek. Az alkalmazott nitrogén trágyaadagok a mintavételek többségében szignifikánsan befolyásolták a növény N-tartalmát.

A mintavételezés első szakaszában (1. és 2. mintavétel) a nitrogénnel jól ellátott növényekben $\left(\mathrm{N}_{175}\right)$ a N-koncentráció kisebb, mint a legkisebb nitrogén-adagnál, de csak a nem öntözött vetésekben szignifikáns a különbség. A számszerü adatok arra engednek következtetni, hogy az 1. és 2. mintavétel idején a növények a talajból is elegendő nitrogénhez jutottak, illetve az $\mathrm{N}_{175}$-kezelésekben a nagyobb zöldtömeg miatt kisebb volt a N-koncentráció.

A N-trágyaadagok hatása a kukorica elemtartalmára

\begin{tabular}{|c|c|c|c|c|c|c|c|c|c|c|c|c|c|}
\hline & & \multirow{2}{*}{\multicolumn{2}{|c|}{ 1. mintavétel(1) }} & \multirow{2}{*}{\multicolumn{2}{|c|}{ 2. mintavétel(2) }} & \multirow{2}{*}{\multicolumn{2}{|c|}{ 3. mintavétel(3) }} & \multirow{2}{*}{\multicolumn{2}{|c|}{ 4. mintavétel(4) }} & \multicolumn{4}{|c|}{ 5. mintavétel(5) } \\
\hline & & & & & & & & & & \multicolumn{2}{|c|}{ Szem(6) } & \multicolumn{2}{|c|}{ Szár(7) } \\
\hline & & $\ddot{0}(8)$ & nö(9) & $\ddot{0}$ & nö & $\ddot{\mathbf{o}}$ & nö & $\ddot{\mathbf{o}}$ & nö & $\ddot{0}$ & nö & $\ddot{\text { ö }}$ & nö \\
\hline \multirow[t]{3}{*}{$N \%$} & $N_{35}$ & 4,63 & 4,85 & 2,15 & 2,48 & 1,23 & 1,68 & 1,13 & 1,33 & 1,35 & 1,38 & 0,48 & 0,50 \\
\hline & $N_{175}$ & 4,53 & 4,58 & 2,38 & 2,00 & $\mathbf{1 , 8 0}$ & 1,75 & 1,50 & 1,43 & 1,53 & 1,50 & 0,83 & 0,85 \\
\hline & $S z D_{5 \%}(10)$ & 0,36 & 0,22 & 0,23 & 0,19 & 0,21 & 0,21 & 0,21 & 0,18 & 0,11 & 0,12 & 0,12 & 0,10 \\
\hline \multirow[t]{3}{*}{$P \%$} & $N_{35}$ & 0,41 & 0,45 & 0,29 & 0,26 & 0,21 & 0,22 & 0,19 & 0,21 & 0,24 & 0,26 & 0,05 & 0,06 \\
\hline & $N_{175}$ & 0,38 & 0,40 & 0,29 & 0,25 & 0,24 & 0,23 & 0,21 & 0,23 & 0,25 & 0,25 & 0,06 & 0,07 \\
\hline & $S z D_{5 \%}$ & 0,03 & 0,06 & 0,03 & 0,03 & 0,03 & 0,03 & 0,03 & 0,04 & 0,02 & 0,02 & 0,01 & 0,02 \\
\hline \multirow[t]{3}{*}{$K \%$} & $N_{35}$ & 4,55 & 4,67 & 4,11 & 3,36 & 2,33 & 2,17 & 1,34 & 1,52 & 0,33 & 0,35 & 0,81 & 0,84 \\
\hline & $N_{175}$ & 4,94 & 4,95 & 3,80 & 3,08 & 2,50 & 2,26 & 1,22 & 0,56 & 0,32 & 0,32 & 0,88 & 0,86 \\
\hline & $S z D_{5 \%}$ & 0,71 & 0,65 & 0,69 & 0,55 & 0,82 & 0,27 & 0,20 & 0,19 & 0,02 & 0,03 & 0,12 & 0,15 \\
\hline \multirow[t]{3}{*}{$\mathrm{Ca} \%$} & $N_{35}$ & 0,55 & 0,56 & 0,34 & 0,33 & 0,25 & 0,28 & 0,23 & 0,26 & 0,01 & 0,01 & 0,30 & 0,32 \\
\hline & $N_{175}$ & 0,51 & 0,60 & 0,38 & 0,36 & 0,28 & 0,3 & 0,26 & 0,31 & 0,01 & 0,01 & 0,33 & 0,39 \\
\hline & $S z D_{5 \%}$ & 0,05 & 0,06 & 0,03 & 0,03 & 0,03 & 0,03 & 0,03 & 0,03 & 0,01 & 0,01 & 0,04 & 0,04 \\
\hline \multirow[t]{3}{*}{$M g \%$} & $N_{35}$ & 0,32 & 0,29 & 0,26 & 0,23 & 0,16 & 0,19 & 0,16 & 0,16 & 0,16 & 0,16 & 0,26 & 0,32 \\
\hline & $N_{175}$ & 0,26 & 0,29 & 0,30 & 0,27 & 0,19 & 0,21 & 0,18 & 0,19 & 0,18 & 0,19 & 0,30 & 0,26 \\
\hline & $\mathrm{SzD}_{5 \%}$ & 0,04 & 0,05 & 0,03 & 0,04 & 0,02 & 0,02 & 0,02 & 0,02 & 0,01 & 0,01 & 0,02 & 0,02 \\
\hline \multirow[t]{3}{*}{$M n \mathrm{mg} / \mathrm{kg}$} & $N_{35}$ & 70,4 & 78,3 & 43,4 & 43,8 & 34,4 & 36,8 & 39,1 & 44,7 & 4,0 & 4,7 & 37,9 & 42,4 \\
\hline & $N_{175}$ & 79,2 & 97,2 & 52,8 & 49,8 & 49,7 & 48,0 & 48,9 & 64,2 & 4,7 & 4,7 & 48,0 & 63,9 \\
\hline & $S z D_{5 \%}$ & 8,5 & 12,0 & 4,9 & 5,4 & 6,7 & 5,4 & 6,3 & 6,8 & 0,3 & 0,5 & 6,9 & 8,0 \\
\hline \multirow[t]{3}{*}{$\mathrm{Zn} \mathrm{mg/kg}$} & $N_{35}$ & 21,8 & 22,4 & 22,7 & 17,8 & 12,8 & 14,4 & 14,3 & 14,0 & 15,5 & 14,9 & 12,6 & 9,6 \\
\hline & $N_{175}$ & 25,1 & 24,7 & 23,1 & 19,2 & 15,2 & 14,5 & 10,1 & 16,6 & 14,3 & 14,0 & 11,9 & 11,1 \\
\hline & $\mathrm{SzD}_{5 \%}$ & 3,4 & 1,8 & 3,6 & 3,2 & 2,5 & 2,3 & 2,5 & 2,1 & 1,5 & 1,5 & 5,1 & 2,6 \\
\hline \multirow[t]{3}{*}{ Cu $\mathrm{mg} / \mathrm{kg}$} & $N_{35}$ & 13,8 & 14,4 & 9,6 & 9,1 & 6,6 & 7,5 & 7,0 & 7,4 & 2,1 & 1,8 & 6,5 & 5,0 \\
\hline & $N_{175}$ & 13,6 & 14,4 & 11,1 & 9,6 & 8,9 & 8,2 & 8,1 & 9,1 & 1,9 & 1,9 & 8,1 & 7,4 \\
\hline & $S z D_{5 \%}$ & 1,1 & 1,3 & 1,0 & 1,0 & 0,9 & 0,7 & 2,2 & 0,7 & 0,2 & 0,2 & 1,1 & 1,6 \\
\hline
\end{tabular}

félkövér kiemelés: 5\%-on szignifikáns eltérés; ö: öntözött, nö: nem öntözött; $\mathrm{N}_{35}: 35 \mathrm{~kg} \mathrm{~N} / \mathrm{ha} ; \mathrm{N}_{175}: 175 \mathrm{~kg} \mathrm{~N} / \mathrm{ha}(11)$ 
A kiválasztott N-kezeléseknek a növény P- és Ktartalmára egyik mintavételnél sem volt statisztikailag kimutatható hatása.

A nitrogén-trágyázás a kukorica növény $\mathrm{Ca}$ - és Mg-tartalmát enyhén növelte. A különbségek csak részben szignifikánsak, ami a talaj viszonylag jó $\mathrm{Ca}$ és Mg-ellátottságára utal, különösen a kezdeti stádiumban.

$\mathrm{Az}$ ammónium-nitrát alkalmazása a talaj savanyodásához vezethet, $\mathrm{s}$ ennek a következményeként az oldott mikroelemek koncentrációja megnő a talajban. Ezt a hatást támasztják alá a kísérlet eredményei is. A nitrogéntrágyázás és a növényi produktum mangán-tartalma között szoros szignifikáns összefüggés állapítható meg. A nagy nitrogén-adaggal trágyázott parcellák növényeinek mangán-koncentrációja a mintavételek többségében nagyobb, mint az $\mathrm{N}_{35}$-kezeléseknél megfigyelhetö értékek (1. ábra).

Ez a hatás már csak kisebb mértékben és tendencia jelleggel érvényesül a növény cink és réz koncentrációjában.

\section{A foszfor-trágyázás és a növény elemkoncentrációjának kapcsolata}

A foszfor-kezelések a minták jelentős részében szignifikánsan befolyásolták a kukorica nitrogéntartalmát (2. táblázat). A vegetációs időszak kezdetén
1. ábra: A N-kezelések hatása a növény Mn-tartalmára öntözött és nem öntözött viszonyok között

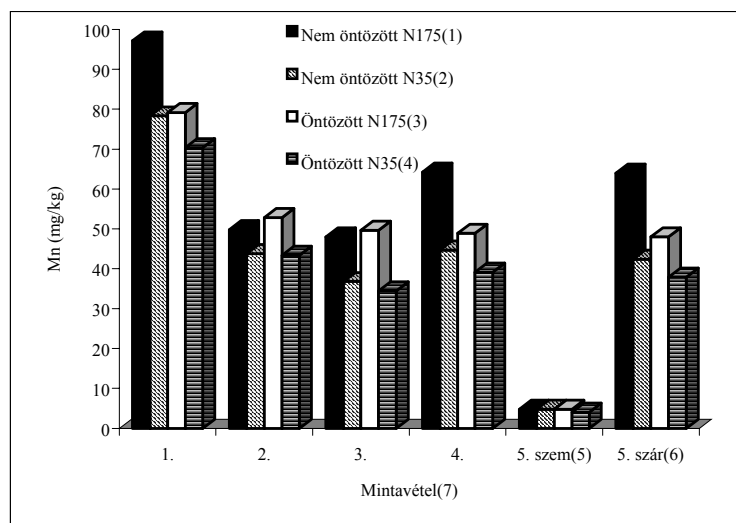

Figure 1: The effect of $N$ treatments on Mn content of the plant with and without irrigation

$\mathrm{N}_{175}$ without irrigation(1), $\mathrm{N}_{35}$ without irrigation(2), $\mathrm{N}_{175}$ with irrigation(3), $\mathrm{N}_{35}$ with irrigation(4), grain(5), straw(6), Sample(7)

(1. mintavétel) a $\mathrm{P}_{140}$-kezelés kisebb nitrogénkoncentrációt eredményezett. A tenyészidő további szakaszaiban a nagyobb foszfor adagok nagyobb nitrogén-tartalmat biztosítottak.

A P-trágyázás hatása a kukorica elemtartalmára

\begin{tabular}{|c|c|c|c|c|c|c|c|c|c|c|c|c|c|}
\hline & & \multirow{2}{*}{\multicolumn{2}{|c|}{ 1. mintavétel(1) }} & \multirow{2}{*}{\multicolumn{2}{|c|}{ 2. mintavétel(2) }} & \multirow{2}{*}{\multicolumn{2}{|c|}{ 3. mintavétel(3) }} & \multirow{2}{*}{\multicolumn{2}{|c|}{ 4. mintavétel(4) }} & \multicolumn{4}{|c|}{ 5. mintavétel(5) } \\
\hline & & & & & & & & & & \multicolumn{2}{|c|}{ Szem(6) } & \multicolumn{2}{|c|}{ Szár(7) } \\
\hline & & $\ddot{0}(8)$ & nö(9) & $\ddot{\mathbf{0}}$ & nö & $\ddot{\mathbf{0}}$ & nö & $\ddot{\mathbf{0}}$ & nö & $\ddot{\mathbf{o}}$ & nö & $\ddot{\mathbf{o}}$ & nö \\
\hline \multirow[t]{3}{*}{$N \%$} & $P_{0}$ & 4,75 & 4,68 & 2,10 & 2,35 & 1,15 & 1,48 & 1,35 & 1,45 & 1,38 & 1,18 & 0,65 & 0,68 \\
\hline & $P_{140}$ & 4,30 & 4,25 & 2,20 & 2,40 & 1,58 & 1,50 & 1,55 & 1,83 & 1,40 & 1,48 & 0,70 & 0,75 \\
\hline & $S z D_{5 \%}(10)$ & 0,36 & 0,22 & 0,23 & 0,19 & 0,21 & 0,21 & 0,21 & 0,18 & 0,11 & 0,12 & 0,12 & 0,10 \\
\hline \multirow[t]{3}{*}{$P \%$} & $P_{0}$ & 0,37 & 0,40 & 0,26 & 0,25 & 0,18 & 0,26 & 0,19 & 0,20 & 0,23 & 0,25 & 0,04 & 0,06 \\
\hline & $P_{140}$ & 0,43 & 0,53 & 0,29 & 0,33 & 0,25 & 0,29 & 0,23 & 0,25 & 0,26 & 0,28 & $\mathbf{0 , 0 7}$ & 0,08 \\
\hline & $S z D_{5 \%}$ & 0,03 & 0,06 & 0,03 & 0,03 & 0,03 & 0,03 & 0,03 & 0,04 & 0,02 & 0,03 & 0,01 & 0,02 \\
\hline \multirow[t]{3}{*}{ K\% } & $P_{0}$ & 4,12 & 4,57 & 3,68 & 3,73 & 2,34 & 2,19 & 1,31 & 1,54 & 0,30 & 0,33 & 0,80 & 0,89 \\
\hline & $P_{140}$ & 4,60 & 5,30 & 3,36 & 3,58 & 2,31 & 2,12 & 1,40 & 1,52 & 0,34 & 0,37 & 0,81 & 0,84 \\
\hline & $S z D_{5 \%}$ & 0,71 & 0,65 & 0,69 & 0,55 & 0,82 & 0,27 & 0,20 & 0,19 & 0,02 & 0,03 & 0,12 & 0,15 \\
\hline \multirow[t]{3}{*}{$\mathrm{Ca} \%$} & $P_{0}$ & 0,55 & 0,51 & 0,33 & 0,32 & 0,26 & 0,28 & 0,24 & 0,25 & 0,01 & 0,01 & 0,36 & 0,32 \\
\hline & $P_{140}$ & 0,52 & 0,58 & 0,34 & 0,39 & 0,26 & 0,28 & 0,26 & 0,30 & 0,01 & 0,01 & 0,31 & 0,35 \\
\hline & $S z D_{5 \%}$ & 0,05 & 0,06 & 0,03 & 0,03 & 0,03 & 0,03 & 0,03 & 0,03 & 0,01 & 0,01 & 0,04 & 0,04 \\
\hline \multirow[t]{3}{*}{$M g \%$} & $P_{0}$ & 0,31 & 0,30 & 0,27 & 0,23 & 0,18 & 0,21 & 0,17 & 0,17 & 0,08 & 0,09 & 0,16 & 0,15 \\
\hline & $P_{140}$ & 0,29 & 0,30 & 0,26 & 0,27 & 0,17 & 0,20 & 0,16 & 0,19 & 0,09 & 0,09 & 0,14 & 0,16 \\
\hline & $S z D_{5 \%}$ & 0,04 & 0,05 & 0,03 & 0,04 & 0,02 & 0,02 & 0,02 & 0,02 & 0,01 & 0,01 & 0,02 & 0,02 \\
\hline \multirow[t]{3}{*}{ Mn $\mathrm{mg} / \mathrm{kg}$} & $P_{0}$ & 71,4 & 80,4 & 45,1 & 46,5 & 40,1 & 44,4 & 39,1 & 50,4 & 4,0 & 4,3 & 45,9 & 45,7 \\
\hline & $P_{140}$ & 76,6 & 109,9 & 45,2 & 50,5 & 40,7 & 40,4 & 48,9 & 56,6 & 4,3 & 4,6 & 49,4 & 49,5 \\
\hline & $S z D_{5 \%}$ & 8,5 & 12,0 & 4,9 & 5,4 & 6,7 & 5,4 & 6,3 & 6,9 & 0,3 & 0,5 & 6,9 & 8,0 \\
\hline \multirow[t]{3}{*}{$\mathrm{Zn} \mathrm{mg/kg}$} & $P_{0}$ & 22,5 & 26,4 & 24,4 & 22,3 & 15,9 & 19,2 & 16,7 & 16,1 & 15,1 & 15,3 & 13,6 & 9,9 \\
\hline & $P_{140}$ & 20,3 & 21,3 & 18,9 & 17,1 & 12,2 & 12,3 & 11,4 & 14,6 & 13,8 & 13,1 & 11,9 & 7,8 \\
\hline & $S z D_{5 \%}$ & 3,4 & 1,7 & 3,6 & 3,2 & 2,5 & 2,3 & 2,5 & 2,1 & 1,5 & 1,5 & 5,1 & 2,6 \\
\hline \multirow[t]{3}{*}{ Cu mg/kg } & $P_{0}$ & 13,4 & 13,1 & 11,1 & 10,8 & 8,0 & 8,8 & 7,4 & 8,4 & 2,0 & 1,8 & 7,5 & 6,2 \\
\hline & $P_{140}$ & 14,2 & 16,7 & 10,3 & 10,1 & 7,4 & 7,7 & 7,4 & 9,0 & 1,9 & 1,7 & 7,0 & 6,0 \\
\hline & $S z D_{5 \%}$ & 1,1 & 1,3 & 1,0 & 1,0 & 0,9 & 0,7 & 2,2 & 0,7 & 0,2 & 0,2 & 1,1 & 1,6 \\
\hline
\end{tabular}

félkövér kiemelés: 5\%-on szignifikáns eltérés; ö: öntözött, nö: nem öntözött, $\mathrm{P}_{0}$ : 0 kg $\mathrm{P}_{2} \mathrm{O}_{5} /$ ha; $\mathrm{P}_{140}$ : $140 \mathrm{~kg} \mathrm{P}_{2} \mathrm{O}_{5} / h$ a(11) 
A növényben a foszfor koncentrációt - néhány kivételtől eltekintve - szignifikánsan növelték a foszfor kezelések. A kukorica K-, Ca-, Mg-tartalma és a foszfor-trágyázás mértéke között összefüggést nem tapasztaltunk.

A mikroelemek közül a növény cink koncentrációját befolyásolta leginkább a foszfor adagolás. A tenyészidő során valamennyi mintavételnél tapasztaltuk a foszfor kedvezötlen hatását a Zn felvételére, bár nem mindegyik koncentrációcsökkenés volt szignifikáns (2.ábra).

$\mathrm{Az}$ irodalom szerint a szuperfoszfát - bár kisebb mértékben, mint az ammónium-sók - szintén savanyítja a talajt. Ennek következményeként a növény mangán-tartalma nő a foszfor-kezelések növekedésével.

\section{Kálium-adagok hatása a növény elemtartalmára}

A kálium-adagolás hatása az egész tenyészidő során érvényesült a kukorica kálium koncentrációjában, növelve annak értékét (3. táblázat). A felhalmozódás dinamikája hasonló, mint a többi elemnél.
2. ábra: A P-adagok hatása a kukorica Zn-koncentrációjára öntözött és nem öntözött viszonyok között

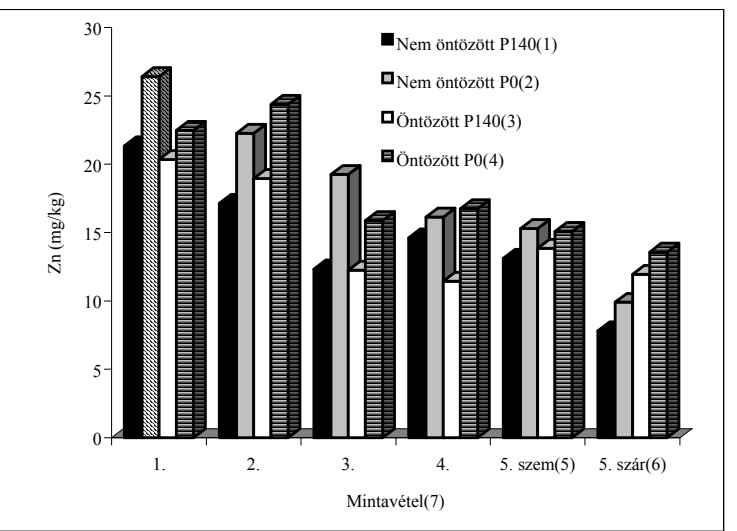

Figure 2: The effect of $P$ fertilization on the concentration of $\mathrm{Zn}$ in the plant with and without irrigation

$\mathrm{P}_{140}$ without irrigation(1), $\mathrm{P}_{0}$ without irrigation(2), $\mathrm{P}_{140}$ with irrigation(3), $\mathrm{P}_{0}$ with irrigation(4), grain(5), straw(6), Sample(7)

A K trágyaadagok hatása a kukorica elemtartalmára

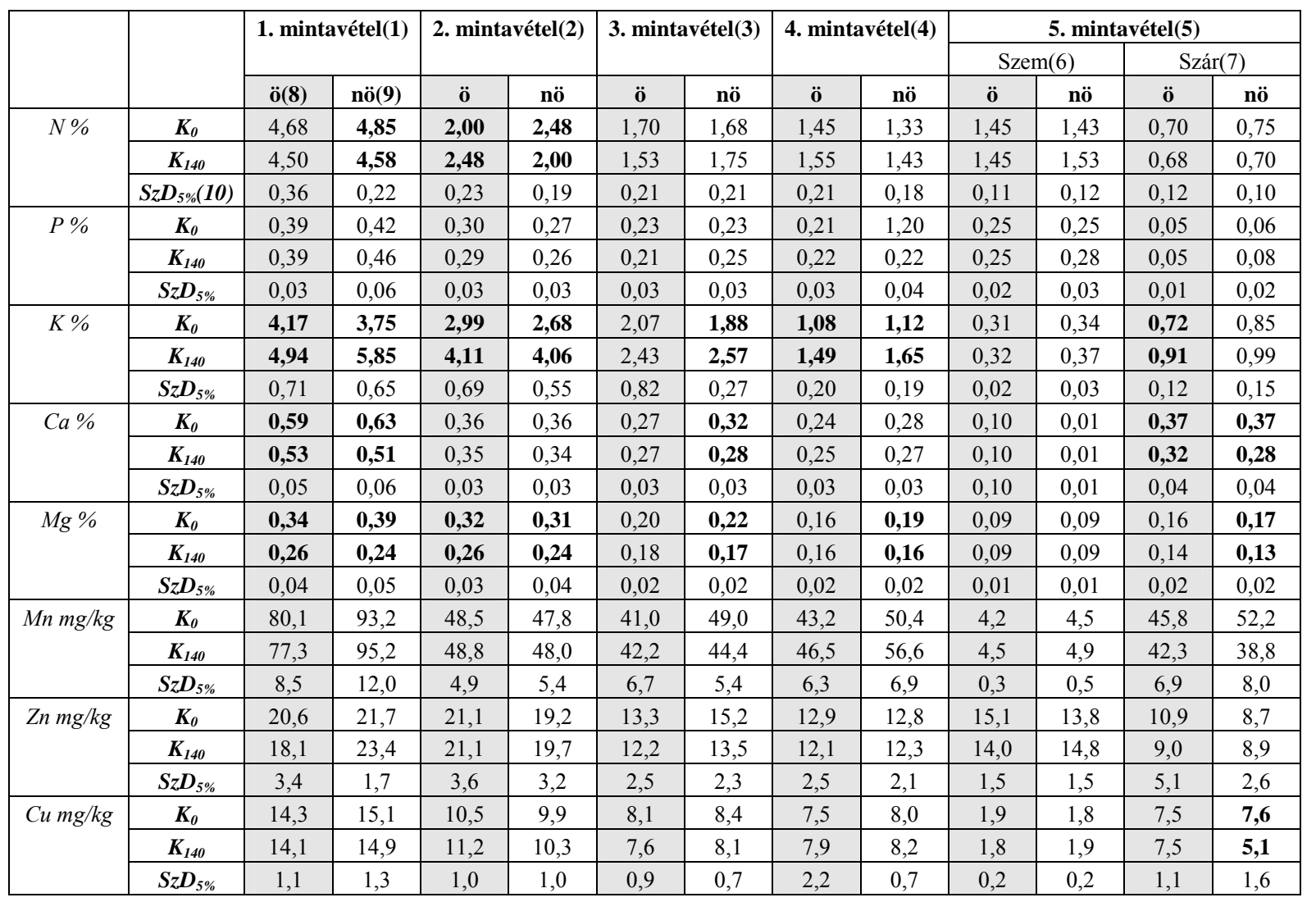

félkövér kiemelés: 5\%-on szignifikáns eltérés; ö: öntözött, nö: nem öntözött, $\mathrm{K}_{0}: 0 \mathrm{~kg} \mathrm{~K} \mathrm{~K}_{2} \mathrm{O} / \mathrm{ha}$; $\mathrm{K}_{140}: 140 \mathrm{~kg} \mathrm{~K} \mathrm{O} / \mathrm{ha}(11)$

Table 3: The effect of $K$ fertilization on nutrient content of maize

$1^{\text {st }}, 2^{\text {nd }}, 3^{\text {rd }}, 4^{\text {th }}, 5^{\text {th }}$ sampling(1), (2), (3), (4), (5), respectively, grain(6), straw(7), irrigated(8), not irrigated(9), least significant difference at $5 \%(10)$, Bold: significant at $5 \%, \mathrm{~K}_{0}: 0 \mathrm{~kg} \mathrm{~K} 2 \mathrm{O} / \mathrm{ha} ; \mathrm{K}_{140}: 140 \mathrm{~kg} \mathrm{~K}_{2} \mathrm{O} / \mathrm{ha}(11)$ 
Elhanyagolható számú és tendenciájában sem felismerhető összefüggést találtunk a káliumtrágyakezelések és a növény nitrogén- ill. foszfor-tartalma között.

Ismert, hogy a talajban lévő kationok $\left(\mathrm{K}^{+}, \mathrm{Ca}^{2+}\right.$, $\mathrm{Mg}^{2+}$ ) szélsőségesen nagy ionarányok esetén gátolhatják egymás felvételét (Loch, 1988). A nagy adagú K-mütrágyázás $\left(\mathrm{K}_{140}\right)$ megváltoztatja az eredeti ionarányokat a talajoldatban, és ez okozza a növény $\mathrm{Ca}$-, $\mathrm{Mg}$-koncentrációjának csökkenését a talajba vitt kálium mennyiség növekedésével. Ezt vizsgálataink is igazolták. (3. ábra).

A növény mikroelem-tartalmát a vizsgált elemeknél, a K-mütrágyázás számottevően nem befolyásolta a látóképi csernozjom talajon.
3. ábra: A növény Mg-tartalmának változása a K-adagok hatására

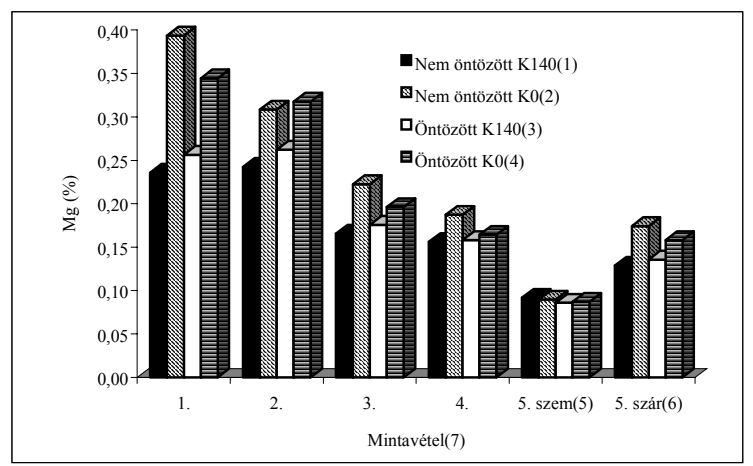

Figure 3: Changes in $\mathrm{Mg}$ content of plant affected by $\mathrm{K}$ doses $\mathrm{K}_{140}$ without irrigation(1), $\mathrm{K}_{0}$ without irrigation(2), $\mathrm{K}_{140}$ with irrigation(3), $\mathrm{K}_{0}$ with irrigation(4), grain(5), straw(6), Sample(7)

IRODALOM

Box, G. E. P.-K. B. Wilson (1951): On the experimental attainment of optimum conditions. J. Royal Stat. Soc. Series B. 13. 1-12.

Kádár I.-Lásztity B. (1981): Az őszi búza tápelemarányainak változása a tenyészidő folyamán. Agrokémia és Talajtan. 30. 291-306.

Kádár I.-Lásztity B. (1997): A zab szárazanyagfelhalmozásának és tápelemtartalmának változása a tenyészidő folyamán. Növénytermelés. 46. 267-274.

Lásztity B. (1989): Néhány mikroelem felvétele a tenyészidő folyamán őszi búza, rozs és triticale növényben. Agrokémia és Talajtan. 38. 395-403.

Lásztity B.-Biczók Gy.-Elek É.-Ruda M. (1985a): A mütrágyázás hatása a kukorica fejlödésére és tápanyagforgalmára. I. Szárazanyag-felhalmozás, tápelemtartalom és tápelemarányok. Agrokémia és Talajtan. 34. 137-160.

Lásztity B.-Biczók Gy.-Elek É.-Ruda M. (1985b): A mütrágyázás hatása a kukorica fejlödésére és tápanyagforgalmára. II. Tápelemfelvétel. Agrokémia és Talajtan. 34. 405-420.

Lásztity B.-Kádár I.-Elek É. (1981): Mütrágyázás hatása az öszi búza tápelemfelvételére barna erdőtalajon. Agrokémia és Talajtan. 30. 25-36.

Loch J. (1988): A termés mennyisége, a növények tápanyagfelvétele és a $\mathrm{K}-, \quad \mathrm{Ca}-$, Mg-ellátás közötti összefüggés. DATE Tudományos Közleményei. 27. 343-362.

Loch J.-Kiss Sz.-Vágó I.-Biczók Gy.-Tolner L. (1987a): A N-, P-, $\mathrm{K}-, \mathrm{Ca}-, \mathrm{Mg}$ - és víz kezelések hatása csernozjom és savanyú homoktalajokon. I. Termésadatok. A mezőgazdaság kemizálása. Keszthely, 1. 53-58.

Loch J.-Kiss Sz.-Vágó I.-Biczók Gy.-Tolner L. (1987b): A N-, P-, $\mathrm{K}$-, Ca-, Mg- és víz kezelések hatása csernozjom és savanyú homoktalajokon. II. A növény tápelemtartalma. A mezőgazdaság kemizálása. Keszthely, 1. 71-77. 